\title{
KOMPARASI PENGGUNAAN ZOOM VS VIDEO TUTORIAL PADA MATAKULIAH KOMPUTASI NUMERIK
}

\author{
Eva Safaah', Wahyuddin ${ }^{2}$ \\ ${ }^{1,2}$ Universitas Serang Raya \\ Jl. Raya Cilegon No.Km. 5 Taman Drangong Kecamatan Taktakan, Kota Serang, Banten 42162 \\ $\underline{{ }^{1} \text { safaah.safaah2020@gmail.com, }}{ }^{2}$ wahyu.unsera@gmail.com
}

\begin{abstract}
ABSTRAK
Lembaga pendidikan mengalami kesulitan untuk menyelenggarakan pendidikan secara daring di era covid19. Kesulitan dalam pemyelenggaraan pendidikan secara online disebabkan belum adanya sarana dan prasarana yang memadai untuk mengatasi masalah tersebut. Kegiatan penelitian dilakukan untuk mengetahui minat mahasiswa/i terhadap media pembelajaran menggunakan zoom conference atau menggunakan media video tutorial terhadap mahasiswa prodi informatikan di Universitas Serang Raya. Pada penelitian ini, teknik pengumpulan data yang dilakukan adalah dengan menyebar angket (kuisioner) pada 112 responden yaitu mahasiswa/i Fakultas Teknologi Informasi yang di ambil secara random sebanyak 6 kelas khusus prodi teknik informatika. Metode penelitian dilakukan secara daring dengan menyebarkan kuisioner secara online melalui WhatsApp. Hasil yang diperoleh seletah dilakukan penelitian, sistem pembelajaran daring yang paling efektif untuk mahasiswa prodi informatika di Fakultas Teknologi Informasi diantara penggunaan platform zoom dan Vidio Tutorial adalah sebanyak $87.5 \%$ dan sebanyak $12.5 \%$ mahasiswa lebih memilih melaksanakan pembelajaran online menggunakan zoom.
\end{abstract}

Kata Kunci: e-learning, zoom, video tutorial, komputasi numerik.

\begin{abstract}
Educational institutions are having difficulty providing online education in the Covid-19 era (Asmuni, 2020). Difficulties in implementing online education are due to the absence of adequate facilities and infrastructure to overcome these problems (Jamaluddin et al., 2020; Pangondian et al., 2019). The research activity was carried out to determine student interest in learning media using zoom conference or using video tutorial media for informatics study program students at Serang Raya University. In this study, the data collection technique used was by distributing questionnaires to 112 respondents, namely students of the Faculty of Information Technology who were taken randomly as many as 6 special classes of informatics engineering study program. The research method was carried out online by distributing online questionnaires via WhatsApp. The results obtained after doing research, the most effective online learning system for students of informatics study program at the Faculty of Information Technology between the use of the zoom platform and the Vidio Tutorial is as much as $87.5 \%$ and as many as $12.5 \%$ of students prefer to carry out online learning using zoom.
\end{abstract}

Key Word: e-learning, zoom, video tutorial, numerical computing.

\section{PENDAHULUAN}

Lembaga pendidikan mengalami kesulitan untuk menyelenggarakan pendidikan secara daring di era covid-19 (Asmuni, 2020). Hal ini dikarenakan belum adanya sarana dan prasarana yang memadai untuk mengatasi masalah tersebut (Jamaluddin et al., 2020; Pangondian et al., 2019).

Dengan pembelajaran daring, penyebaran covid-19 dapat diminimalisir karena dosen dan mahasiswa tidak bertemu dan bertatap muka secara langsung. Interaksi antar mahasiswa pun dapat dilakukan secara online sehingga kontak langsung bisa diminimalisir dan penyebaran covid-19 bisa diminimalisir. Adapun media on line yang digunakan oleh mahasiswa Jurusan Olah raga dan Kepelatihan FKIP Universitas Jambi adalah zoom cloud meeting, google clasroom, google meet, moodle, LMS Universitas Jambi dan whatshap. Penggunaan zoom cloud meeting memudahkan dalam proses pembelajaran daring (Naserly, 2020).

Pembelajaran jarak jauh dapat mempersingkat waktu pembelajaran dan tentu saja dapat menghemat biaya yang harus dikeluarkan oleh lembaga pendidikan (Silahuddin, 2015). Keberhasilan pembelajaran jarak jauh tidak hanya 
bergantung pada materi atau isi yang disajikan oleh pendidik, melainkan pada bagaimana proses penyampaian materi tersebut, agar peserta didik dapat memahami materi yang disampaikan oleh pendidik. Model pembelajaran yang dapat dilakukan pada anak usia dini dimasa pandemi Covid-19 ini adalah pembelajaran jarak jauh, pembelajaran yang idealnya memiliki interaktifitas antara pendidik dan peserta didik walaupun tidak dalam satu tempat yang sama, dengan adanya video conference akan membantu proses pembelajaran yang dilakukan, karena pendidik akan terlibat langsung dengan peserta didik (Sandiwarno, 2016).

Video conference dinilai juga efektif dalam mengatasi ruang jarak, dan waktu (Sidiq, 2015). Pembelajaran dengan video conference ini mampu mengoptimalkan kreativitas dalam pembelajaran (Hazari \& Thompson, 2015). Pembelajaran melalui video conference selain dapat mengoptimalkan adanya interaksi secara langsung antara anak didik, pendamping anak belajar dan pendidik, juga dapat menampilkan materi pembelajaran di tampilan dan dapat dilihat oleh semua partisipan, sehingga partisipan tidak hanya mendengar penjelasan melainkan dapat juga mencermati materi yang diberikan (Holland, 2014, Sandiwarno, 2016) .

Salah satu aplikasi yang menyediakan fasilitas interaksi tatap muka pendidik dan peserta didik secara virtual melalui video conference dengan PC atau laptop atau smartphone adalah Zoom Cloud Meeting, aplikasi ini merupakan aplikasi yang digunakan sebagai media komunikai jarak jauh dengan menggabungkan konferensi video, obrolan, pertemuan online dan kolaborasi seluler. Penggunaan meeting dalam aplikasi ini bisa menampung 1000 peserta bersama dalam satu pertemuan secara virtual. Aplikasi ini dapat didownload secara gratis, tetapi tetap fungsional, fitur yang ada antara lain panggilan telephone, webinar, presentasi, dan masih banyak lainnya. Aplikasi ini dinilai punya kualitas yang baik, dapat dibuktikan dengan perusahaan yang sudah masuk dalam fortune 500 sudah menggunakan layanan ini. (Wibawanto, 2020).

Pelaksanaan pembelajaran jarak jauh membutuhkan media yang dapat mendistribusikan ilmu pengetahuan atau sebagai wadah dalam proses kegiatan belajar mengajar. Media yang digunakan sebagai sarana pembelajaran jarak jauh sekarang ini menggunakan internet disebut juga dengan online learning yang dapat memberikan fasilitas koneksi keseluruh penjuru dunia. Internet yang tidak dibatasi jarak dan waktu membuat pembelajaran dapat dilakukan kapan saja dan dimana saja, penggunaan internet sebagai sarana belajar dapat memberikan dampak yang positif dalam penggunaan internet dengan peran para pendidik dalam pengelolahannya agar pembelajaran dapat terlaksana dengan efektif (Nugroho, 2012). Pembelajaran yang efektif adalah pembelajaran yang dapat memanfaatkan teknologi informasi dan komunikasi dengan optimal sebagai alat bantu (Hanum, 2013).

Keuntungan penggunaan pembelajaran online adalah pembelajaran bersifat mandiri dan interaktivitas yang tinggi, mampu meningkatkan tingkat ingatan, memberikan lebih banyak pengalaman belajar, dengan teks, audio, video dan animasi yang semuanya digunakan untuk menyampaikan informasi, dan juga memberikan kemudahan menyampaikan, memperbarui isi, mengunduh, para siswa juga bisa mengirim email kepada siswa lain, mengirim komentar pada forum diskusi, memakai ruang chat, hingga link videoconference untuk berkomunikasi langsung (Arnesti \& Hamid, 2015).

Upaya peningkatan mutu pendidikan di indonesia selalu menjadi isu penting dalam penyelenggaraan Sistem Pendidikan Nasional. Peningkatan kualitas pendidikan ini menjadi salah satu strategi pokok selain pemerataan kesempatan dan akses pendidikan serta peningkatan relevansi dan efisiensi.

Pada masa pandemi COVID-19 dan sejak di berlakukannya WFH, universitas serang raya melakukan sistem pembelajaran secara 
daring. Metode pembelajaran daring yang dilakukan diantaranya adalah menggunakan media zoom meeting, video tutorial, whats app group, dan sistem informasi yang disediakan universitas serang raya. Penelitian ini dilakukan untuk mengetahui media pembelajaran apa yang paling diminati mahasiswa antara media pembelajaran menggunakan zoom meeting atau media pembelajaran menggunakan media video tutorial khususnya di fakultas teknologi informatika pada prodi informatika untuk matakuliah komputasi numerik.

Rumusan masalah pada penelitian ini adalah penelitian hanya membandingkan 2 media pembelajaran yaitu antara zoom conference dan media video tutorial. Berdasarkan rumusan masalah di atas, maka tujuan yang ingin dicapai dari perancangan ini adalah untuk mengetahui minat mahasiswa/i terhadap media pembelajaran menggunakan zoom conference atau menggunakan media video tutorial terhadap mahasiswa yang sedang menjalani pendidikan di Universitas Serang Raya.

Dengan adanya program working dan learning from home terkait adanya pandemi Virus Corona permintaan untuk pasang internet di rumah meningkat. Jumlah pelanggan baru pada Maret meningkat 30 persen sampai dengan 40 persen dibandingkan dengan bulan sebelumnya (www.cnn.indonesia.com). Demikian halnya dengan aplikasi rapat yang ada, seperti aplikasi zoom pada 26 Maret 2020, Aplikasi Zoom mencatatkan sebanyak 257,853 pengguna, di mana pada minggu sebelumnya 19 Maret 2020, aplikasi ini berada pada angka 91.030 orang. Di sisi lain, aplikasi posisi Zoom diikuti oleh Skype di posisi kedua yang mencatatkan 71.155 pengguna, dengan indikasi mengalami kenaikan sebesar 8,02 persen kenaikan dari pengguna sebelumnya yang mencapai 65.875 orang. Untuk aplikasi selanjutnya, Hangouts Meet mengalami peningkatan trafik yang cukup signifikan lewat penggunaan di masyarakat pada 19 Maret 2020 mencapai 7.917 yang meningkat pada 26 Maret 2020 sebesar 10.454 pengguna, dengan kenaikan sebesar 32, 14 persen. (www.Teknologi.bisnis.com/ penggunaan-aplikasi-conference, 17 April 2020).

\section{METODE PENELITIAN}

Pada penelitian ini, metode pengumpulan data yang dilakukan adalah dengan menyebar angket (kuisioner) pada 112 responden yaitu mahasiswa /i prodi informatika Fakultas Teknologi Informasi yang di ambil secara random sebanyak 6 kelas. Data dalam penelitian ini dilakukan dengan cara menyebarkan kuisioner secara online melalui WhatsApp.

Teknik pengumpulan data yang digunakan adalah kuesioner atau angket. Menurut Sugiyono (2015: 199) kuesioner merupakan teknik pengumpulan data yang dilakukan dengan cara memberi seperangkat pertanyaan atau pernyataan tertulis kepada responden untuk dijawabnya. Data-data yang diperlukan dari responden dapat dihimpun melalui angket atau kuesioner. Angket tersebut berupa pertanyaanpertanyaan tertutup yang diberikan pada responden. Data kuantitatif skor penilaian yang diperoleh dari hasil pengisian angket ahli media pembelajaran dan ahli materi pembelajaran, dianalisis dengan menggunakan skala Likert dan skala Guttman.

Skala likert (Method of Summated Rating) menghadirkan sejumlah pertanyaan positif dan negatif tentang suatu objek sikap. Dalam menjawab butir-butir dalam skala ini subjek memilih: sangat setuju, setuju, ragu-ragu, tidak setuju, sangat tidak setuju. (Sugiyono, 2018:124) pengumpulan data yang dilakukan dengan memberikan pertanyaan secara tertulis kepada responden untuk di jawab dalam bentuk angket. Angket ini merupakan teknik pengumpulan data yang efisien bila peneliti tahu dengan pasti variabel yang akan diukur dan tahu apa yang bisa diharapkan dari responden.

Teknik pengumpulan data pada penelitian ini dilakukan menggunakan teknik wawancara menggunakan google form dan disebarkan melalui whatsapp kepada 6 kelas prodi informatika untuk matakuliah Komputasi Numerik di universitas serang raya sebanyak 112 mahasiswa/i. 


\section{HASIL DAN PEMBAHASAN}

Hasil penelitian dilakukan dengan pengujian kuisioner yang diberikan kepada mahasiswa fakultas teknologi informasi prodi informatika pada Universitas Serang Raya. Hasil pengujian tersebut adalah sebagai berikut:

a. Persentase kesulitan mahasiswa terhadap kuota internet pada saat kuliah daring

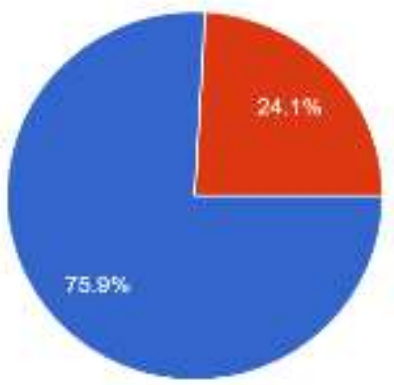

Gambar 1. Persentase Tingkat Kesulitan Mahasiswa Terhadap Kuota Internet Dari gambar diatas terlihat bahwa dari 112 responden terdapat $75.9 \%$ mahasiswa mengalami kesulitan kuota internet pada saat kuliah daring.

b. Persentase tingkat kenyamanan untuk perkuliahan daring jika kuota internet memadai.

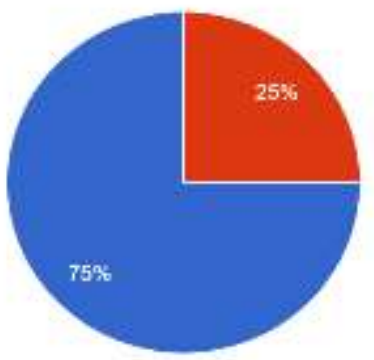

Gambar 2. Tingkat Kenyamanan Pada Perkuliahan Daring

Dari gambar 4.2 terlihat bahwa $75 \%$ dari 112 mahasiswa merasa nyaman mengakses video pembelajaran yang di upload dosen di youtube dibandingkan pembelajaran menggunakan spada saja.

c. Kepemilikan Akun Youtube

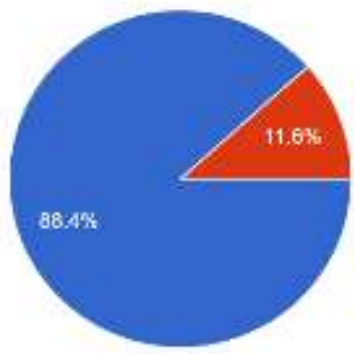

Gambar 3. Jumlah Kepemilikan Akun Youtube
Dari gambar di atas terlihat bahwa dari 112 responden yang di ambil secara random terdapat $88.4 \%$ mahasiswa memiliki akun youtube dan sebanyak $11.6 \%$ tidak memiliki akun youtube

d. Platform Yang Disenangi Untuk Pembelajaran Online diantaranya Zoom Atau Video Tutorial

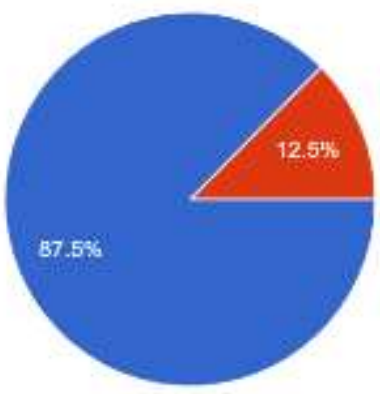

Gambar 4. Platform Yang Disenangi (Zoom Atau Video Tutorial)

Dari gambar diatas terlihat bahwa untuk mebelajaran online mahasiswa lebih memilih menggunakan vidio tutorial sebanyak $87.5 \%$ dan sebanyak $12.5 \%$ mahasiswa lebih memilih melaksanakan pembelajaran online menggunakan zoom.

\section{SIMPULAN DAN SARAN}

Pada matakuliah komputasi numerik, sistem pembelajaran daring yang paling efektif untuk mahasiswa prodi informatika di Fakultas Teknologi Infoermasi diantara penggunaan platform zoom dan Vidio Tutorial adalah sebanyak $87.5 \%$ dan sebanyak $12.5 \%$ mahasiswa lebih memilih melaksanakan pembelajaran online menggunakan zoom.

\section{UCAPAN TERIMAKASIH}

Peneliti mengucapkan terimakasih sebesarbesarnya kepada Universitas Serang Raya Prodi Informatika yang telah mendukung segala kegiatan penelitian ini dari awal kegiatan sampai selesainya penelitian ini.

\section{DAFTAR PUSTAKA}

Abdillah, L. A., \& Darma, U. B. (2020). Online Learning Menggunakan Zoom Teleconference.

Ahmadi, Abu. (2009). Psikologi Sosial. Jakarta: Rineka Cipta.

Arnesti, N., \& Hamid, A. (2015). Penggunaan Media Pembelajaran Online - Offline Dan Komunikasi Interpersonal Terhadap Hasil Belajar Bahasa Inggris. 
Jurnal Teknologi Informasi \& Komunikasi Dalam Pendidikan, 2(1). https://doi.org/10.24114/ jtikp.v2i1.3284.

Asmuni, A. (2020). Problematika Pembelajaran Daring di Masa Pandemi Covid-19 dan Solusi Pemecahannya. Jurnal Paedagogy, 7(4), 281-288. https://doi.org/https://doi.org/10.33394/j p.v7i4.2941.

Bimo, Walgito. (2010). Pengantar Psikolog Umum. Yogyakarta: C.V Andi.

Djaali. (2008). Psikologi Pendidikan. Jakarta: Bumi Aksara.

Djamarah, Syaiful Bahri. (2011). Psikologi Belajar. Jakarta: Rineka Cipta.

Gerlach, S. Vernon,1980, Teaching and Media, New Jersey, Prentice- Hall.,Inc.

Hanum, N. S. (2013). Keefetifan e-learning sebagai media pembelajaran (studi evaluasi model pembelajaran e-learning SMK Telkom Sandhy Putra Purwokerto). Jurnal Pendidikan Vokasi, 3(1), 90-102. https://doi.org/10.21831/jpv.v3i1.1584.

Hartanto, W. (2016). Penggunaan E-Learning sebagai Media Pembelajaran. Jurnal Pendidikan Ekonomi, 10(1), 1-18.

Jamaluddin, D., Ratnasih, T., Gunawan, H., \& Paujiah, E. (2020). Pembelajaran Daring Masa Pandemik Covid-19 Pada Calon Guru : Hambatan, Solusi dan Proyeksi. Karya Tulis Ilmiah UIN Sunan Gunung Djjati Bandung, 1-10. http://digilib.uinsgd.ac.id/30518/

Kemdikbud RI. (2020). Edaran Tentang Pencegahan Wabah COVID-19 di Lingkungan Satuan Pendidikan Seluruh Indonesia.

Kementerian Dalam Negeri. (2020). Pedoman Umum Menghadapi Pandemi COVID-19 Bagi Pemerintah Daerah. 1$206 . \quad$ https://doi.org/10.1017/ CBO9781107415324.004.

Kementerian Kesehatan. (2020). Pedoman Pencegahan dan Pengendalian Coronavirus Disease (COVID-19). 3, 1116.

Maudiarti, Santi. (2018). Penerapan ELearning di Perguruan Tinggi. Perspektif Ilmu Pendidikan, 32 (1), 5368.

Naserly, M. K. (2020). Implementasi Zoom, Google Classroom, Dan Whatsapp
Group Dalam Mendukung Pembelajaran Daring (Online) Pada Mata Kuliah Bahasa Inggris Lanjut (Studi Kasus Pada 2 Kelas Semester 2, Jurusan Administrasi Bisnis, Fakultas Ekonomi dan Bisnis, Universitas Bina Sa. Aksara Public, 4(2), 155-165.

Nugroho, A. (2012). Pengembangan Model Pembelajaran. Jurnal Transformatika, 9, No 2, 29-44.

Pangondian, R. A., Paulus, S. I., \& Nugroho, E. (2019). Faktor - Faktor Yang Mempengaruhi Kesuksesan Pembelajaran Daring Dalam Revolusi Industri 4.0. Seminar Nasional Teknologi Komputer \& Sains (SAINTEKS), 56-60. https://seminarid.com/semnas-sainteks2019.html

Sandiwarno, S. (2016). Perancangan Model E-Learning Berbasis Collaborative Video Conference Learning Guna Mendapatkan Hasil Pembelajaran yang Efektif dan Efisien. Jurnal Ilmiah FIFO, $8(2)$,

191. https://doi.org/10.22441/fifo.v8i2.1314

Silahuddin, S. (2015). Penerapan E-Learning dalam Inovasi Pendidikan. CIRCUIT: Jurnal Ilmiah Pendidikan Teknik Elektro, 1(1), 48-59. https://doi.org/10.22373/crc.v1i1.310.

Slameto. (2010). Belajar dan FaktorFaktor yang Mempengaruhinya. Jakarta: Rineka Cipta.

Wibawanto, T. (2020). Pemanfaatan Video Conference Dalam Pembelajaran Tatap Muka Jarak Jauh Dalam Rangka Belajar Dari Rumah.

Windhiyana Pratiwi, E. (2020). Dampak Covid-19 Terhadap Kegiatan Pembelajaran Online Di Sebuah Perguruan Tinggi Kristen Di Indonesia. Perspektif Ilmu Pendidikan. Volume 34 Issue 1 April 2020. p-ISSN: 1411-5255. e-ISSN: $2581-2297 . \quad$ DOI: doi.org/10.21009/PIP.341.1

https://www.cnnindonesia.com/teknologi/202 00408124947-213-

491594/penggunainternet-kala-wfhcorona-meningkat-40-persen-di-ri 